\title{
The influence of mechanical resistance on the development and life-period of cells.
}

\author{
FREDERICK C. NEWCOMBE.
}

(Concluded from p. 199.)

\begin{abstract}
The effect of external mechanical resistance on the duration of the life-period of cells.
\end{abstract}

The fact that meristem in growing points, in the cambium and in zones of plants that increase by intercalary growth, may preserve its functional capability for many weeks while the tissue is held in an apparently inactive condition by gypsum casts has already been shown. From what is now to follow it will appsar that the life-period of cells may be prolonged if their growth or that of neighboring cells is mechanically restrained.

After young aerial shoots of Juncus effusus had been, withfor some time, the longest period being eleven weeks, that part of the shoot above the meristem showed a thicker living peripheral zone of tissue than was there present when the shoot was put into gypsum, and thicker than normally occurs at any time in this stem. The greater thickness was not dependent on a radial elongation of cells so much as on an innumber normally number of circular rows of cells over the with, the shoot in elongat. If growth had not been interfered increased the in elongating and enlarging radially would have by first the size of its dead central mass of stellate cells most rows of living cells. As it was, the central cylinder of
cells that were crushed together by the when the cast was applied had been while the latter by the inward push of the newly formed cells

Two shoots of Equise much beyond their usual life-period. than $3^{\mathrm{em}}$ or $4^{\mathrm{em}}$ above not nearly completed the ground and whose internodes had sum that the apex of their elongation were so encased in gypfor three weeks reaching a stem was left free. Thus they grew stems increased but slightly in diameter in this time and the 
internodes within the casts did not elongate. In these internodes the intercarinal canals had not formed in one plant, their place being occupied by living cells, while in the other plant but two or three cells had died in each of those positions. Above and below the limits of the casts the canals were of large size. It need hardly be mentioned that normally these canals arise mostly by the destruction of cells. Similar preparations to the foregoing but in which the stems were left in the gypsum twice as long, had, when examined, canals within as well as without the casts.

A young plant of Zea mais the lower part of whose stem was so encased in gypsum as to prevent elongation of one of its internodes to one-third of what it would have been, had not within the cast thirty-seven days afterwards formed the usual lysigenous canals in the vascular bundles, the thinwalled cells being there undisturbed and living, while in other parts of the stem they were destroyed. Here since there was but slight constriction of stem made by the cast, the prolongation of the life of the cells in question is probably to be referred to the checking of the elongation of the internode.

The growth of the leaves of Allium cepa is not easily confined by a surrounding cast; since, when the tip of the leaf is left free the organ glides through the gypsum because of the very smooth surface of the former. This gliding can be prevented, however, by bending the leaf into a zigzag course and so fixing it before the gypsum is poured on. By pursuing such a method young leaves have been encased and the parts within casts have been kept from becoming inflated while all cells remained alive. In the same leaves, above and below the casts the normal inflation took place two or three days after the casts were applied. The longest period that the central cells of such leaves within casts have been kept alive is fifteen days, or from eleven to twelve days after such cells had died in parts outside the casts.

Sachs ${ }^{14}$ has shown that if an onion is germinated in the dark, its leaves will not become hollow. Histologically this means that the normally assimilating cells of the periphery will not be developed in their usual $\mathrm{H}$-palisade form, when light is absent. It is at the time of the rapid extension of the peripheral cells of the young leaf to the dimensions of these assimilating cells that the central hyaline mass of the

14 Sachs: Ueber den Einfluss des Tageslichtes auf Neubildung und Entfal tung verschiedener Planzenorgane. Botanische Zeitung, Beilage. 1863. 
leaf is torn and the leaf changes from the thin, sword-shape to the inflated. The cast effects what darkness effects; in both cases tha small peripheral cells remain undeveloped. But casts better than darkness preserve the life of the central, hyaline cells, since the larger etiolated leaves always undergo considerable peripheral extension and always show a narrow cavity lined by fragments of destroyed cells. That this central part of the leaf has not been kept alive longer than about two weeks is accounted for by the fact that at about that time the leaf, which is plano-convex, in its effort to expand folds inward on its flat side, thus crushing the delicate central cells.

The petiole of Ricinus communis when unextended contains no central cavity, but a wide one extended. By applying casts the death of this central mass of tissue has been prevented for about three weeks longer within than outside the casts.

With the rhizome of Triticum repens a similar result was obtained, the internodes being allowed to reach not one-half their normal size, and the cavity appearing above and below the casts before appearing within.

Before elongation was complete, casts were put around the stems of Caltha palustris, Lamium garganicum, Urtica dioica and Vicia faba. All of these plants form central cavities during elongation or at its termination, partly by the schizogenous partly by the lysigenous method. All of them have preserved alive the pith of those parts of the stem within the casts longer than in the parts outside the casts. The period of this preservation was not determined for any species; nor is it a matter probably of much moment since the duration of the period depends largely on the time of application of the cast relative to the development of the part concerned. The younger the organ is when enclosed in gypsum, the longer will its cells remain alive. It should be stated that the longest period of experiment was that in the case of Vicia faba, in which several individuals were found with pith wholly living within the casts I 6 days after it would have died normally. In the third internode above the cotyledons, the internode used in these experiments, the cavity normally in in which the pith had been preserved for 116 days longer than usual had reached nearly a meter in height and had seed-pods
half grown. 
Similarly to the cells of the pith, the life-period of the cortical cells has also been prolonged. Lamium garganicum, Urtica dioica and Vicia faba have shown dead cells in the cortex outside the limits of the casts, when within the casts all cells have remained alive.

There have come under my observation two species of plants in which, sometimes but not always, cortical cells are crushed within the casts before any dead ones appear outside the casts. These plants are Ricinus communis and Dahlia variabilis. This result is apparently brought about by the growth of the fibrovascular zone, the turgor there present being sufficient to cause the less resistant cells of the cortex to collapse, whereas similar cells outside the limits of the casts live for some time longer, though the tissue which they form becomes looser and looser by the separation of cells.

In all of the foregoing cases in which the life-period of cells has been more than normally prolonged, the cells were prevented from attaining their full size by confining their growth before they were fully extended. But in certain cases the death of cells may be deferred by checking the growth of surrounding tissue after the cells in question have reached their full extension. In Sambucus nigra and Helianthus tuberosus, for instance, where the pith lives for several weeks after secondary growth has begun, a cast applied after the pith has grown to its definitive size will preserve the pith alive for several weeks after it dies above and below the limits of the cast.

\section{Summary.}

I. Meristematic tissue of growing points, intercalary zones and cambium will preserve for a considerable period its functional capability when growth is prevented by an external mechanical resistance.

II. When in such meristematic tissue growth is checked by mechanical resistance, the tissue remains apparently unaltered; the cells do not divide, nor the walls become thicker, nor the composition of the walls undergo change.

Especial attention may be called to the biological significance of the two facts just stated, and to the resemblance to what takes place when growth ceases because of cold or insufficient moisture. It is manifestly to the interest of the plant-organism not only that the life of meristematic tissue should be retained but that the primary condition of this tis- 
sue should be retained, instead of the passing of such tissue over into a permanent state where growth could not be resumed when the obstacle to growth should be removed.

If it should be found-what neither Pfeffer, Krabbe nor I have once observed-that in some plants the cell-walls of the meristem become slightly thicker during the enforced rest of this tissue, as Krüger ${ }^{15}$ found thickenings to arise in the radial walls of the cambium of some plants during the winter rest, the importance of the biological truth would not be altered, that the meristem retains its functional capability.

That the cell-contents may change during mechanical resistance was shown by Pfeffer ${ }^{16}$ in the case of the primary root of Vicia faba, where there was a considerable rise of turgor after the root was enclosed in a gypsum cast. This rise of turgor does not take place in all plants, as Pfeffer showed.

III. The period between the formation of a cell and the arrival at its definitive condition is lengthened by an external resistance preventing or impeding growth.

Under this general statement is included a group of phenomena the details of which may be the better emphasized by greater individual prominence, such as the following:

I. The zone of eiongation in roots and stems passes more slowly into its definitive length.

2. Differentiation of the fundamental parenchyma into collenchyma, sclerenchyma and sclerenchymatous parenchyma proceeds more slowly.

3. All the thick-walled and lignified elements of the bundles develop more slowly.

It has already been stated that De Vries discovered this for elements of the xylem. The observations here recorded show that it holds true for the hard bast also.

4. The formation of cork is deferred.

This statement is in accord with the results obtained with the' three plants under experiment and also with Gerber's ${ }^{17}$ results in placing ligatures about stems. Since, as has been shown in this article and in the investigations of others, cells do not divide under pressure till they have reached or nearly

\footnotetext{
${ }^{15}$ Krüger: Ueber die Wandverdickungen der Cambiumzellen. Botanische
Zeitung 50: 663 . 1892.

${ }^{17}$ Perfer: Druck-und Arbeitsleistung, 65 .

iger Bäume. Ueber die jährliche Kork-production im Oberflächen-periderm ein-
} 
reached their normal dimensions, and since cork-formation must be accomplished by extension and division of cells, it follows as a probability that cork-formation is delayed by pressure because of the mechanical resistance to cell-extension. But since cork-formation is attended by the death of externally lying cells, it is easily seen that soon after the formation of the phellogen, an external ligature or gypsum band will exert no immediate pressure in those cases where the phellogen is some distance within the periphery of the stem, simply because of the contraction of the dying tissue between the phellogen and the external ligature or band. Thus it seems probable that if external resistance is applied early enough to prevent the normal extension of the cells in which the phellogen usually appears, the formation of cork may be indefinitely postponed. If however the cells normally giving rise to the phellogen attain their full dimensions before the external resistance is applied we may expect the phellogen to be formed and cork-formation to proceed more or less slowly according to the greater or less vitality displayed by the cells external to the phellogen, and also according to the depth of phellogen within the cortex.

In this connection it is worth noting that $\mathrm{Krabbe}^{18}$ found cork to arise deep within the cortex when a very great pressure was applied to the trunks of trees, this phenomenon being abnormal. This is certainly a regulatory act performed by the plant, but whether to regard it as a means of furnishing more room for the growth of the cambium cannot be decided with the lack of detail touching the accompanying phenomena as given by Krabbe. It may be mentioned however that Melianthus major, though the cork appears within an enveloping cast more tardily than outside of it, eventually frees itself completely from the resistance of the cast by the very act of cork-formation, the activity of the cambium from that time forward being usually great.

IV. Under the pressure of a mechanical resistance cells reach their permanent condition with smaller size and thinner walls than normal.

V. Cells which usually die early have their life-period prolonged when their full extension or that of properly related adjacent cells is prevented by an external mechanical resistance.

As appears from the narrative of the experimental part of

${ }^{18} \mathrm{Krabbe}$ : Ueber das Wachsthum des Verdickungsringes, etc. 1. c. 
this article, the statement just made is founded principally on the behavior of the cells of the fundamental parenchyma. It was found in all cases where cells normally dying early were kept from reaching their full size that their life-period was extended. In certain cases also it was found that the pith of plants will live longer than usual if a gypsum cast is put around the stem after the pith has reached its full size, the cast, however, preventing the surrounding tissues of the stem from enlarging. It is probable that in the latter case, the pith lives because of the regulatory action of the plant, the usual more peripheral tissues not being formed, new duties are laid upon the pith. Such regulatory action accounts for the phenomenon discovered by De Vries ${ }^{19}$ in Pelargonium zonale. In this case the flower axis bore among the flowerbuds a vegetative bud which developed into a shoot, and the flower axis instead of withering as usual lived to function as a vegetative axis.

It is probable also that in the first group of experiments in which the cells were not allowed to reach their normal size that the same cause operated to prolong the life-period. Yet was made upon them for transport of material nor for other function that can be thought of; the same could probably be said for the stems of Equisetum and the leaves of Allium enclosed in casts. In the case of the leaves of Allium when grown in darkness, we have the direct evidence that it is not the use of the central cells for purposes of transport that keeps them alive. In such cases it is probable the cells in question remain alive longer than normally because the conditions for their existence are not so unfavorable; that is, they live because the surrounding tissues are not allowed by their growth to pull these cells apart and thus bring them into unfavorable future article. This question will be farther considered in a

The experiments recorded in this paper have been scarcely life-ped enough in time to demonstrate the extension of the life-period of the elements of the fibrovascular bundle. That ing elements also live longer than normally when surround10 ${ }^{19}$ De Vries: Ueber abnormale Entstehung secundärer Gewebe. Jahrb. f.
wiss Bot. 22:-1891. 
from the examples which all have noticed of vines twining about trees or of ligatures left unintentionally for years about trees. Since the elements of the bundle of woody plants normally live but a few years, it follows that beneath a ligature, such as those just mentioned, which has prevented radial extension in a tree for many years, the elements of the bundles must live longer than normally, otherwise we should have the whole zone dying and the stem above the ligature also dying.

VI. If during primary or early secondary extension in a dicotyledonous stem, with pith of not great resistance, radial growth be prevented by external mechanical means, there will follow a displacement of the fascicular'zone toward the axis of the stem, caused principally by the extension of the cortical cells. Later, however, the cortex will be crowded back by the growth of the fascicular zone.

VII. When an external pressure is great enough to prevent the derivatives of the cambium from attaining their normal size, the cambium will still continue to form new cells. This is an expression of the fact that the power of extension in the cambium is greater than that in derivatives of the cambium some distance removed from it.

University of Michigan, Ann Arbor. 


\section{$2 \mathrm{BHL}$ Biodiversity Heritage Library}

Newcombe, Frederick C . 1894. "The Influence of Mechanical Resistance on the Development and Life-Period of Cells (Concluded)." Botanical gazette 19(6), 229-236. https://doi.org/10.1086/327052.

View This Item Online: https://www.biodiversitylibrary.org/item/93164

DOI: https://doi.org/10.1086/327052

Permalink: https://www.biodiversitylibrary.org/partpdf/222369

\section{Holding Institution}

Missouri Botanical Garden, Peter H. Raven Library

\section{Sponsored by}

Missouri Botanical Garden

\section{Copyright \& Reuse}

Copyright Status: Public domain. The BHL considers that this work is no longer under copyright protection.

This document was created from content at the Biodiversity Heritage Library, the world's largest open access digital library for biodiversity literature and archives. Visit BHL at https://www.biodiversitylibrary.org. 